\title{
Precocious pseudopuberty due to virilising adrenocortical carcinoma progressing to central precocious puberty after surgery
}

\author{
Alpesh Goyal, ${ }^{\circledR}$ Rakhi Malhotra, Rajesh Khadgawat
}

Endocrinology and Metabolism, All India Institute of Medical Sciences, New Delhi, Delhi, India

\section{Correspondence to Dr Alpesh Goyal, alpeshgoyal89@gmail.com}

Accepted 23 February 2019

Check for updates

(c) BMJ Publishing Group Limited 2019. No commercial re-use. See rights and permissions. Published by BMJ.

To cite: Goyal A, Malhotra R, Khadgawat R. BMJ Case Rep 2019;12:e229476. doi:10.1136/bcr-2019229476

\section{DESCRIPTION}

A 7-year-old boy presented to our department with a 8-month history of progressive phallus enlargement and premature appearance of pubic and axillary hair. Parents also noticed increased irritability and aggressive behaviour in the child during this period. They denied any history of acneiform eruptions, malodorous secretions, deepening of voice, muscular prominence or rapid height and weight gain in the child. No history of headache, blurring of vision, seizures, cranial irradiation, perinatal trauma, past encephalitis, exogenous exposure to sex steroids, mucocutaneous hyperpigmentation, salt wasting crisis, lump abdomen, scrotal mass, bony pains, bony deformities or any hyperpigmented birthmarks could be elicited. There was no history suggestive of isosexual or contrasexual precocity in any other family members. Clinical examination found an alert and active child with height of $120 \mathrm{~cm}(50-75$ th centile), weight of $22 \mathrm{~kg}$ (25-50th centile) and mid-parental height of $171.5 \mathrm{~cm}$ (50-75th centile). The child had enlarged phallus measuring $9.5 \mathrm{~cm}$, Tanner stage 4 pubic hair and abundant axillary hair. He had prepubertal testes, measuring $2 \mathrm{~mL}$ bilaterally by Prader orchidometer. No cushingoid stigmata, mucocutaneous hyperpigmentation, café au lait macules, bony deformities or palpable abdominal lump were noted on clinical examination.

On investigation, he had normal renal and liver function tests, serum electrolytes and thyroid function tests. Basal testosterone, dehydroepiandrosterone sulfate (DHEAS) and 17-hydroxyprogesterone (17-OHP) were elevated at $34.3 \mathrm{nmol} / \mathrm{L}$ (normal range for age $<0.1-0.3 \mathrm{nmol} / \mathrm{L}),>27.1 \mu \mathrm{mol} / \mathrm{L}$ (normal for age $<1.1 \mu \mathrm{mol} / \mathrm{L}$ ) and $>61.7 \mathrm{nmol} / \mathrm{L}$ (normal for age $<3.3 \mathrm{nmol} / \mathrm{L}$ ), respectively. Gonadotropin-releasing hormone (GnRH) agonist test performed using $100 \mu \mathrm{g}$ triptorelin revealed a stimulated luteinising hormone (LH) level of 0.5 $\mathrm{IU} / \mathrm{L}$, suggestive of $\mathrm{GnRH}$-independent precocious puberty (precocious pseudopuberty). His bone age, calculated by Greulich and Pyle method was advanced at 13 years. Further investigations revealed loss of diurnal variation of serum cortisol, elevated midnight salivary cortisol, non-suppressed serum cortisol on low-dose dexamethasone suppression test and suppressed adrenocorticotropin (ACTH) level of $<0.1 \mathrm{pmol} / \mathrm{L}$ (normal range $1.6-13.9 \mathrm{pmol} / \mathrm{L}$ ), suggestive of ACTH-independent hypercortisolism. On the basis of clinical findings and biochemical investigations, an adrenal source of androgen and glucocorticoid excess was suspected and patient underwent CT of abdomen. CT abdomen revealed a large heterogeneously enhancing right suprarenal mass lesion measuring $13.5 \mathrm{~cm} \times 10.4 \mathrm{~cm} \times$ $10.4 \mathrm{~cm}$ abutting the inferior surface of right lobe of liver and pushing right kidney posteroinferiorly, without any evidence of regional lymphadenopathy or liver metastases (figure 1). He underwent rightsided open adrenalectomy and was initiated on hydrocortisone supplementation in the postoperative period. Histopathology of the excised adrenal mass was suggestive of adrenocortical carcinoma (ACC). On postoperative day 7 , he was discharged with serum testosterone of $<0.1 \mathrm{nmol} / \mathrm{L}$, DHEAS of $0.4 \mu \mathrm{mol} / \mathrm{L}$ and $17-\mathrm{OHP}$ of $1.4 \mathrm{nmol} / \mathrm{L}$. At postoperative 6 months, the parents brought him with the reappearance of pubic hair. Examination revealed testicular volume of $8 \mathrm{~mL}$ bilaterally, scrotal rugosities and pigmentation, and Tanner stage 4 pubic hair. Serum DHEAS and 17-OHP levels were normal; however, testosterone was elevated at $2.1 \mathrm{nmol} / \mathrm{L}$ and child had pubertal basal $\mathrm{LH}$ value of $2.1 \mathrm{IU} / \mathrm{L}$, suggestive of $\mathrm{GnRH}$-dependent precocious puberty (central precocious puberty). He was started on GnRH analogue treatment using depot leuprolide injection, with subsequent arrest of pubertal progression.

Precocious puberty is defined as appearance of secondary sexual characteristics before the age of 8 years in girls and 9 years in boys. ${ }^{1}$ Premature pubertal maturation can be caused by GnRH-dependent or

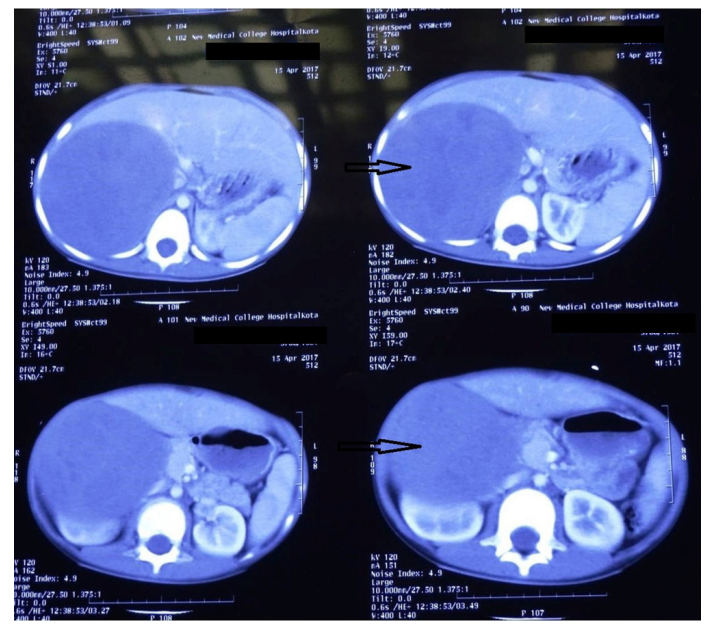

Figure 1 CT of abdomen showing a large, heterogeneously enhancing right suprarenal mass (arrow). 
Table 1 Differences between gonadotropin-releasing hormone (GnRH)-dependent and GnRH-independent precocious puberty

\begin{tabular}{|c|c|c|}
\hline Parameter & GnRH-dependent precocious puberty & GnRH-independent precocious puberty \\
\hline Nature of puberty & Isosexual & Isosexual or heterosexual \\
\hline Sequence of pubertal events & Similar to normal puberty & Disordered \\
\hline Height velocity & $\begin{array}{l}\text { Increased. Normal if coexistent growth hormone } \\
\text { deficiency }\end{array}$ & Increased. Decreased in hypothyroidism \\
\hline Cycles of breast growth and regression (girls) & Absent & May be present \\
\hline Testicular size (boys) & Symmetric increase appropriate for pubertal stage & $\begin{array}{l}\text { Prepubertal/asymmetric increase/symmetric increase but } \\
\text { small for pubertal stage }\end{array}$ \\
\hline GnRH stimulation test & Luteinising hormone $(\mathrm{LH})$ peak in pubertal range & LH peak in prepubertal range \\
\hline Common aetiologies & $\begin{array}{l}\text { Hypothalamic hamartoma, astrocytoma, previous } \\
\text { encephalitis, radiation exposure, hydrocephalus }\end{array}$ & $\begin{array}{l}\text { Congenital adrenal hyperplasia, adrenal neoplasm, } \\
\text { hypothyroidism, } \\
\text { McCune-Albright syndrome, familial testotoxicosis, } \\
\text { exogenous sex steroid intake }\end{array}$ \\
\hline
\end{tabular}

GnRH-independent causes (table 1). Childhood ACC, a rare cause of $\mathrm{GnRH}$-independent precocious puberty, is hormonally active in $>90 \%$ cases, and manifests as virilisation with or without hypercortisolism in most patients. $^{2}$ Coexistent hypercortisolism may attenuate the positive effect of sex steroid excess on the current height of an individual, as was seen in our patient. Steroid hormone biosynthesis in ACC is relatively inefficient, resulting in elevated levels of steroid precursors such as 17-OHP and 11-deoxycorticosterone. Chronically elevated levels of sex steroids from peripheral source may lead to activation of

\section{Learning points}

- Childhood adrenocortical carcinoma is a rare cause of gonadotropin-releasing hormone $(\mathrm{GnRH})$-independent precocious puberty.

- It may present with isosexual or heterosexual precocity.

- Such children should be followed closely in the postoperative period for development of GnRH-dependent precocious puberty due to activation of hypothalamic $\mathrm{GnRH}$ pulse generator. hypothalamic GnRH pulse generator, resulting in central precocious puberty, which may appear even after successful treatment of the peripheral source. ${ }^{3}$ It is, therefore, important to clinically follow such patients postoperatively, not only for local recurrence, but also for secondary effects for long-standing peripheral sex steroid excess.

Contributors AG, RM and RK diagnosed and managed the patient, carried out a literature search, collected data about the case and drafted the manuscript. All the authors reviewed and revised the final manuscript.

Funding The authors have not declared a specific grant for this research from any funding agency in the public, commercial or not-for-profit sectors.

Competing interests None declared.

Patient consent for publication Parental/guardian consent obtained.

Provenance and peer review Not commissioned; externally peer reviewed

\section{REFERENCES}

1 Carel J-C, Léger J. Precocious Puberty. N Engl J Med Overseas Ed 2008;358:2366-77.

2 Michalkiewicz E, Sandrini R, Fiqueiredo B, et al. Clinical and outcome characteristics of children with adrenocortical tumors: a report from the International Pediatric Adrenocortical Tumor Registry. J Clin Oncol 2004:22:838-45.

3 Kim MS, Yang EJ, Cho DH, et al. Virilizing adrenocortical carcinoma advancing to central precocious puberty after surgery. Korean J Fam Med 2015;36:150-3.

Copyright 2019 BMJ Publishing Group. All rights reserved. For permission to reuse any of this content visit https://www.bmj.com/company/products-services/rights-and-licensing/permissions/

BMJ Case Report Fellows may re-use this article for personal use and teaching without any further permission.

Become a Fellow of BMJ Case Reports today and you can:

- Submit as many cases as you like

- Enjoy fast sympathetic peer review and rapid publication of accepted articles

- Access all the published articles

- Re-use any of the published material for personal use and teaching without further permission

For information on Institutional Fellowships contact consortiasales@bmjgroup.com

Visit casereports.bmj.com for more articles like this and to become a Fellow 